\title{
Chromosomal evolution in genus Carex as viewed from nuclear DNA content, with special reference to its aneuploidy1)
}

\author{
By Kozo NishIKawa, Yoshihiko FuRUTA and Kaoru IsHITOBI \\ Faculty of Agriculture, Gifu University, Gifu 501-11
}

(Received June 26, 1984)

\begin{abstract}
In order to consider characteristic chromosomal evolution, agamatoploidy in genus Carex, nuclear DNA content of metaphase plates in root tip of $\mathbf{5 0}$ cytologically stable strains belonging to 26 species of Carex collected in Japan was measured Feulgen cytophotometrically.

Considerably large variation was observed in six species with rather high chromosome number. There was 7.7 times variation in DNA content among species analyzed in the present study. As assumed by earlier reports, it is presumed that $C$. siderosticta $4 \mathrm{x}$ and $C$. humilis were derived from $C$. siderosticta $2 \mathrm{x}$ and $C$. humilis ssp. nana, respectively.

Among diploid species, 4.66 times but continuous variation was observed. There were no significant differences in nuclear DNA among four aneuploid of $C$. oxyandra and five of C. conica, respectively. Neither of five couples of strains, each belonging to a single species and having the same chromosome number but collected at different sites revealed any differences, indicating intraspecific aneuploid resulted from simple change of chromosome number. Three pairs of close relatives, $C$. foliosissima vs. C. morrowii, C. paxii vs. C. nubigera and C. pumila vs. C. kobomugi, were similar to each other in DNA content. It is clear that the increase in chromosome number is accompanied by the decrease in nuclear DNA content; negative correlation and regression between DNA content and chromosome number were confirmed to be highly significant in $\mathbf{4 5}$ diploid species.

Based on the evidence of various kinds of earlier investigrtions and the present study, it is suggested that species with many small chromosomes would be derived from species having small number of large chromosomes by means of fragmentation followed by slight reduction of DNA.
\end{abstract}

\section{INTRODUCTION}

Family Cyperaceae comprises about 45 genera including more than 4000 species. One of them, genus Carex contains about 1800 species which are distributed throughout the world, predominantly in Asia and northern America. The plants in this genus are characterized by chromosomes with non-localized centromere or holocentric chromosomes and wide range of variation in chromo-

1) Contribution from The Laboratory of Geneties and Plant Breeding, Faculty of Agriculture. Gifu University, No. 64. 
some number ( $\mathrm{n}=6$ to 68 ), resulting in so-called Carex type aneuploidy or agamatoploidy (Tanaka 1939, 1948, Devies 1956). Tanaka (1948) pointed out that total chromosome volume in species with the small number of chromosomes was remarkably larger than that in species of high chromosome number. Recently, Hoshino (1981b) reported that the size of chromosome in intraspecific aneuploids decreased according to the increase in chromosome number and that polyploidy might have played only a minor role in the speciation of this genus. But he supported the theory of chromosome differentiation by agamatoploidy proposed by Devies (1956) and Faulkner (1972).

In order to consider this characteristic chromosomal evolution in genus Carex, nuclear DNA content of 50 strains belonging to 26 species of Carex collected in Japan was measured by Feulgen-cytophotometry.

\section{MATERIALS AND METHODS}

Cytologically stable 50 strains of 26 species shown in Table 1 were kindly provided by Dr. T. Hoshino, Okayama University of Science and used in the present study. Root tips were fixed in fresh acetoethanol fluid in May to June or September to October, rinsed in ethanol series and stocked in $75 \%$ ethanol in refrigerator. Root tips of C. ciliato-marginata used as the standard and five strains to be compared with the standard were hydrolyzed together in $5 \mathrm{~N} \mathrm{HCl}$ at $25^{\circ} \mathrm{C}$ for 30 minutes, stained in Schiff's reagent $\left(25^{\circ} \mathrm{C}\right)$ for 3 hours in dark, washed in potassium pyrosulfite solution three times for 15 minutes each and squashed. Immediately after staining, spherical metaphase cells were measured at $556 \mathrm{~nm}$ by Nikon-Vickers M85 Scanning Microdensitometer. When it was possible, ten metaphase plates of each root tip and three root tips of each strain per replication were selected for measurement and three replications were carried out ${ }^{*}$

\section{RESULTS AND DISCUSSION}

Fig. 1 is the histogram of nuclear DNA content at various mitotic stages in root tip of C. ciliato-marginata. The DNA values measured in interphase and prophase nuclei widely varied, while those of nuclei at metaphase and anaphase, particularily at metaphase, converged on the limited range of variation (Fig. 1). Then, it is apparent that metaphase plate is suitable for measurement of DNA content of each nucleus. DNA content of nucleus in 50 strains belonging to 26 species in Carex is shown in Table 1 . Considerably large variation was observed in six species, C. tristachya (coefficient of variation, 18\%), C. capillacea (13\%), C. brownii (15\%), C. thunbergii (14\%), C. paxii (17\%) and C. nubigera (14\%). These species are rather high in chromosome number and include intraspecific aneuploids. But, it is not explainable why DNA content of nucleus is so variable even within a given individual plant. 
Table 1. Nuclear DNA content at metaphase in strains belonging to 26 species of genus Carex (arbitrary unit)

\begin{tabular}{|c|c|c|c|c|c|c|}
\hline \multirow{2}{*}{$\begin{array}{c}\text { Strain } \\
\text { number }\end{array}$} & \multirow{2}{*}{ Section and species } & \multirow[b]{2}{*}{$2 n$} & \multirow{2}{*}{$\begin{array}{l}\text { No. of } \\
\text { nuclei }\end{array}$} & \multicolumn{3}{|c|}{ Nuclear DNA content (4C) } \\
\hline & & & & $\operatorname{Mean} \pm \mathrm{SE}$ & $\mathrm{CV}^{*}$ & $\begin{array}{l}\text { Significant } \\
\text { at } 5 \%\end{array}$ \\
\hline & Laxiflorae & & & & & \\
\hline 1 & C. ciliato-marginata & 12 & 1000 & $225 \pm 1$ & 7 & $d^{* *}$ \\
\hline 2 & C. pachygyna & 12 & 90 & $296 \pm 2$ & 6 & b \\
\hline 3 & C. pachygyna & 12 & 75 & $285 \pm 2$ & 5 & $\mathrm{bc}$ \\
\hline 4 & $\begin{array}{l}\text { C. siderosticta } 4 x \\
\text { Digitatae }\end{array}$ & 24 & 90 & $471 \pm 3$ & 6 & a \\
\hline 5 & C. oxyandra & 18 & 80 & $162 \pm 1$ & 7 & jklm \\
\hline 6 & C. oxyandra & 20 & 90 & $166 \pm 1$ & 3 & $\mathrm{jkl}$ \\
\hline 7 & C. oxyandra & 20 & 60 & $155 \pm 1$ & 5 & lmnop \\
\hline 8 & C. oxyandra & 24 & 90 & $162 \pm 1$ & 6 & jklm \\
\hline \multirow[t]{2}{*}{9} & C. oxyandra & 26 & 90 & $161 \pm 1$ & 6 & jklm \\
\hline & C. humilis & & & & & \\
\hline 10 & ssp. lanceolata & 72 & 90 & $292 \pm 2$ & 6 & bc \\
\hline \multirow[t]{2}{*}{11} & ssp. lanceolata & 72 & 60 & $269 \pm 3$ & 8 & c \\
\hline & Decorae & & & & & \\
\hline 12 & C. reinii & 26 & 90 & $197 \pm 2$ & 10 & defghi \\
\hline 13 & C. chrysolepis & 28 & 90 & $160 \pm 1$ & 6 & jklmn \\
\hline 14 & C. makinoensis & 30 & 90 & $163 \pm 1$ & 7 & $\mathrm{jklm}$ \\
\hline \multirow[t]{2}{*}{15} & C. blepharicarpa & 30 & 90 & $182 \pm 1$ & 7 & ghijk \\
\hline & Praecoces & & & & & \\
\hline 16 & C. conica & 32 & 90 & $175 \pm 1$ & 7 & $\mathrm{ijkl}$ \\
\hline 17 & C. conica & 32 & 90 & $176 \pm 1$ & 7 & hijkl \\
\hline 18 & C. conica & 36 & 80 & $181 \pm 1$ & 7 & ghijk \\
\hline 19 & C. conica & 36 & 90 & $179 \pm 1$ & 8 & ghijkl \\
\hline 20 & C. conica & 38 & 90 & $183 \pm 1$ & 7 & fghij \\
\hline 21 & C. conica & $?$ & 60 & $178 \pm 1$ & 6 & ghijkl \\
\hline 22 & C. conica & $?$ & 60 & $173 \pm 2$ & 7 & $\mathrm{ijkl}$ \\
\hline 23 & C. foliosissima & 30 & 90 & $208 \pm 1$ & 5 & def \\
\hline 24 & C. morrowii & 38 & 90 & $200 \pm 1$ & 5 & defgh \\
\hline 25 & var. temnolepis & 38 & 90 & $208 \pm 2$ & 8 & defg \\
\hline \multirow[t]{2}{*}{26} & var. albo-marginata & 30 & 80 & $198 \pm 2$ & 8 & defghi \\
\hline & C. dolichostachya & & & & & \\
\hline 27 & var. glaberrima & $62-70$ & 90 & $157 \pm 1$ & 8 & klmno \\
\hline \multirow[t]{2}{*}{28} & C. laticeps & 58 & 90 & $132 \pm 1$ & 9 & opqr \\
\hline & C. oahuensis & & & & & \\
\hline \multirow[t]{2}{*}{29} & ssp. robusta & 62 & 80 & $106 \pm 1$ & 8 & stu \\
\hline & C. tristachya & & & & & \\
\hline 30 & ssp. pocilliformis & $?$ & 60 & $124 \pm 3$ & 18 & qrst \\
\hline
\end{tabular}

(to be continued) 
Table 1. (Continued)

\begin{tabular}{|c|c|c|c|c|c|c|}
\hline \multirow{2}{*}{$\begin{array}{c}\text { Strain } \\
\text { number }\end{array}$} & \multirow[b]{2}{*}{ Section and species } & \multirow[b]{2}{*}{$2 n$} & \multirow{2}{*}{$\begin{array}{l}\text { No. of } \\
\text { nuclei }\end{array}$} & \multicolumn{3}{|c|}{ Nuclear DNA content $(4 \mathrm{C})$} \\
\hline & & & & Mean \pm SE & $\mathrm{CV}^{*}$ & $\begin{array}{l}\text { Significant } \\
\text { at 5\% }\end{array}$ \\
\hline 31 & C. pisiformis & 68 & 90 & $138 \pm 1$ & 7 & mnopq \\
\hline 32 & ssp. alterniflora & $60-84$ & 60 & $131 \pm 1$ & 7 & pqrs \\
\hline 33 & ssp. duvaliana & 76 & 60 & $125 \pm 1$ & 9 & qrst \\
\hline 34 & ssp. stenostachya & 58 & 90 & $131 \pm 1$ & 8 & pqrs \\
\hline \multirow[t]{2}{*}{35} & var. ikegamiana & 58 & 90 & $130 \pm 1$ & 9 & pqrs \\
\hline & Extensae & & & & & \\
\hline 36 & C. bostrychostigma & 46 & 90 & $222 \pm 1$ & 6 & de \\
\hline 37 & C. capillacea & $60-66$ & 80 & $101 \pm 1$ & 13 & tu \\
\hline 38 & C. ischnostachya & 62 & 60 & $110 \pm 2$ & 10 & rstu \\
\hline \multirow[t]{2}{*}{39} & C. brownii & 72 & 90 & $87 \pm 1$ & 15 & uv \\
\hline & Atratae & & & & & \\
\hline \multirow[t]{3}{*}{40} & C. curviollis & 56 & 90 & $135 \pm 1$ & 9 & nopqr \\
\hline & Graciles & & & & & \\
\hline & C. sendaica & & & & & \\
\hline \multirow[t]{2}{*}{41} & ssp. nakiri & 62 & 90 & $133 \pm 1$ & 7 & opqr \\
\hline & Carex & & & & & \\
\hline 42 & C. shimidzensis & 68 & 60 & $126 \pm 2$ & 9 & qrst \\
\hline 43 & C. maximowiczii & $68-74$ & 60 & $118 \pm 1$ & 7 & qrst \\
\hline 44 & C. kiotensis & 74 & 70 & $121 \pm 1$ & 9 & qrst \\
\hline \multirow[t]{2}{*}{45} & C. thunbergii & $78-90$ & 70 & $119 \pm 2$ & 14 & qrst \\
\hline & Paludosae & & & & & \\
\hline \multirow[t]{2}{*}{46} & C. pumila & 82 & 60 & $110 \pm 1$ & 9 & rstu \\
\hline & Vignea & & & & & \\
\hline 47 & C. omiana & $48-58$ & 90 & $118 \pm 1$ & 9 & qrst \\
\hline 48 & C. kobomugi & 88 & 80 & $89 \pm 1$ & 10 & $\mathrm{u}$ \\
\hline \multirow[t]{2}{*}{49} & C. paxii & 76 & 70 & $62 \pm 1$ & 17 & vw \\
\hline & C. nubigera & & & & & \\
\hline 50 & ssp. albata & 112 & 60 & $61 \pm 1$ & 14 & $\mathrm{w}$ \\
\hline
\end{tabular}

* coefficient of variation $(\%)$

** no difference between strains with the same alphabet.

Variance analysis revealed highly significant difference among strains. The result of test of significance among means of strains is shown in the rightmost column in Table 1. Nuclear DNA content of the highest species, $C$. siderosticta 4x (DNA content, 471) was 7.72 times that of the least DNA species, $C$. nubigera (61). Mello-Sampayo (1961) and Halkka (1964) reported 6 times variation in DNA content among species of Luzula with holocentric chromosomes. Tanaka (1940) frequently observed tetravalents at meiosis in species with the highest DNA value, $C$. siderosticta $4 \mathrm{x}$ and assumed that this plant 


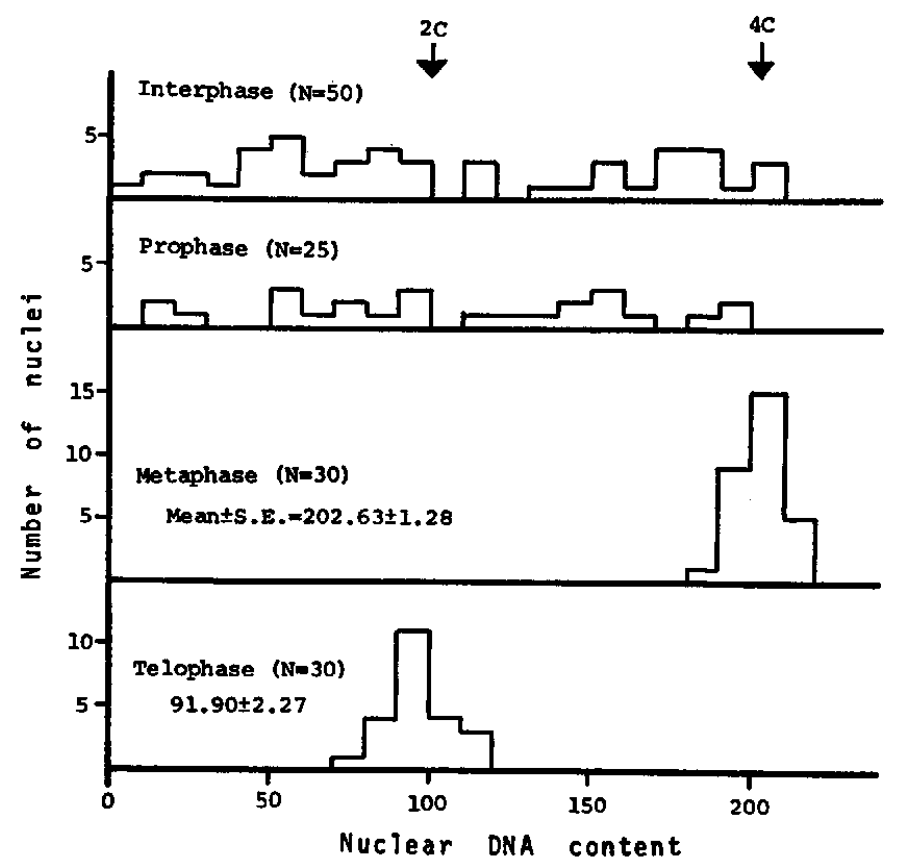

Fig. 1. Distribution of nuclear DNA content at four stages of mitosis in root tip of $C$. ciliato-marginata $(2 \mathrm{n}=12)$.

was autotetraploid derived from C. siderosticta $2 \mathrm{x}$ which is distributed in Kanto district of Japan, but unfortunately was not available in the present study. Moreover, Hoshino (1981b) supported Tanaka's assumption by identifying duplication in the number of darkly stained segments in distal region of mitotic prophase chromosomes. DNA value in this tetraploid (471) was nearly twice of that of $C$. ciliatomarginata $(2 n=12,225)$ which is a close relative to diploid strain of $C$. siderosticta. Another tetraploid, C. humilis (Tanaka 1984) had also indeed more DNA (269 or 292). Tanaka (1948) mentioned that this tetraploid species might be derived from $C$. humilis ssp. nana, which was not available in the present study.

Among diploid species, nuclear DNA content varied from 285 in C. pachygyna $(2 \mathrm{n}=12)$ to 61 in C. nubigera $(2 \mathrm{n}=112)$ or 62 in C. paxii $(2 \mathrm{n}=76)$, indicating 4.66 times variation in diploid species of this genus. In genus Carex, a number of intraspecific aneuploids and the geographical cline in their distribution were reported (Hoshino 1980, $1981 \mathrm{a}$ and b). Hoshino (1981b) pointed out the difference in total volume of metaphase chromosome among intraspecific aneuploids. There were, however, no significant differences in nuclear DNA content among four different kinds of aneuploid of C. oxyandra $(2 \mathrm{n}=18$ to 26$)$ or five of $C$. conica $(2 \mathrm{n}=32$ to 38$)$ (Table 1). Additionally, neither of five couples of strains, each belonging to a single species and having 


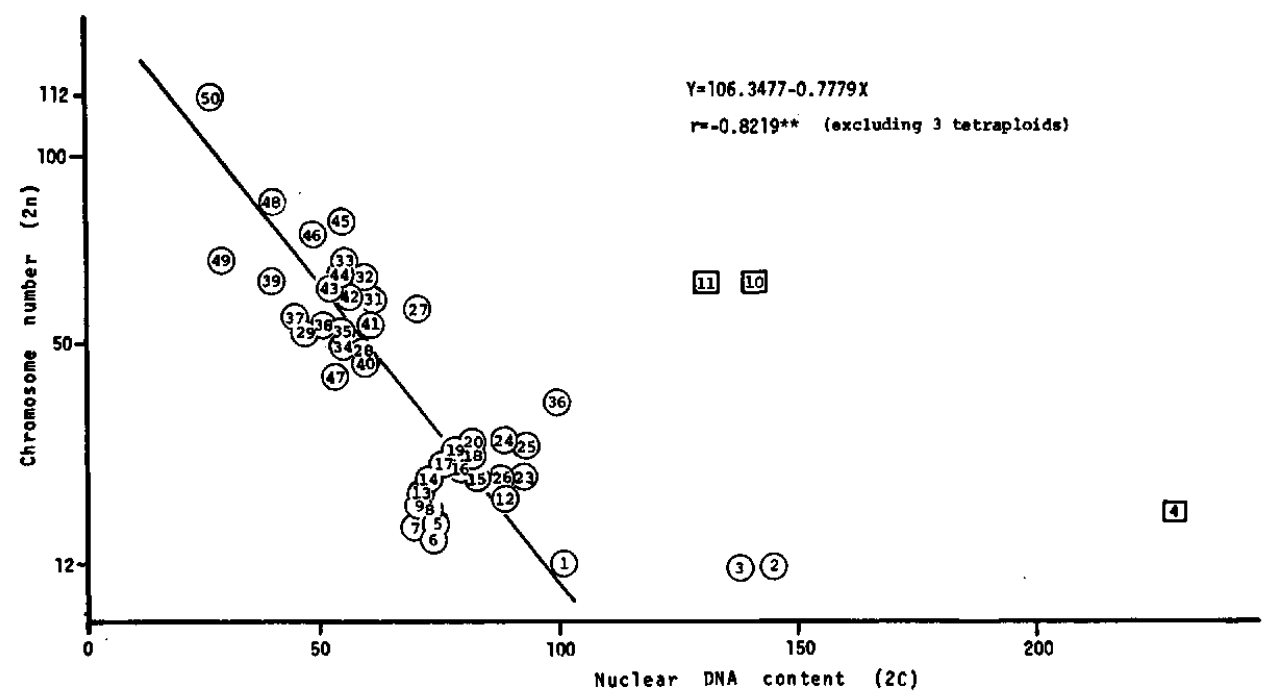

Fig. 2. Relationship between chromosome number and nuclear DNA content in 47 strains of the genus Carex. Circle and square show diploid and tetraploid, respectively. Number in circle or square indicates strain number listed in Table 1.

the same chromosome number but collected at different sites (C. pachygyna $(2 \mathrm{n}=12)$, C. oxyandra $(2 \mathrm{n}=20)$, C. humilis $(2 \mathrm{n}=72)$ and 2 pairs of C. conica $(2 \mathrm{n}=32,36))$ revealed any differences in DNA content (Table 1). At least, it seems that these intraspecific aneuploids resulted from simple change of chromosome number caused by fragmentation or fusion, but without deficiency and/or duplication of chromosome segment. DNA content of three pairs of close relatives, $C$. foliosissima $(2 \mathrm{n}=30$, DNA value; 208$)$ vs. $C$. morrowii $(38,200), C$. paxii $(76,62)$ vs. C. nubigera $(112,61)$ and $C$. pumila $(82,110)$ vs. C. kobomugi $(88,89)$ was similar to each other, respectively.

Nuclear DNA contents of 47 strains were plotted against their chromosome number (Fig. 2). C. pachygyna with minimum number of chromosome $(2 \mathrm{n}=$ 12) had the highest DNA content, contrastingly the least amount of DNA was found in C. paxii $(2 \mathrm{n}=76)$ and C. nubigera with the highest chromosome number $(2 n=112)$. Hoshino (1981b) concluded that total chromosome volume decreased slightly with the increase of chromosome number. At a glance of Fig. 2, it is clear that the increase in chromosome number is accompanied by the decrease in nuclear DNA content. Namely, highly significant negative correlation and regression between DNA content and chromosome number were confirmed in 45 diploid strains of the genus Carex used in the present study. Although Tanaka (1952) reported two peaks at $2 n=38$ and 68 in relation to distribution of chromosome number of 203 species and few species between $2 \mathrm{n}=44$ to 50, belonging to subgenus Eucarex, nuclear DNA content varied continuously among species used in this study (Table 1, Fig. 2). 
According to karyological study (Tanaka 1948; Hoshino 1981b), morpho-taxonomical study (Koyama 1957) and morphological study of development of inflorescence (Smith 1966), it is likely that C. pachygyna $(2 \mathrm{n}=12)$, C. ciliatomarginata (12) and $C$. siderosticta (12) belonging to section Laxiflorae are primitive, while that $C$. paxii (76) and $C$. nubigera (112) of section Vignea are the advanced type. In the major course of speciation of genus Carex, it seems to be a logical conclusion that species with many small chromosomes would be derived from species having the small number of large chromosomes by means of fragmentation followed by slight reduction of DNA content (La Cour 1952, Castro et al. 1954). Hoshino (1981b), classified 49 taxa of Carex into two types of interphase nuclei, complex and simple chromocenter types, by double staining of leucobasic fuchsin and aceto-orcein. Complex chromocenter type was found in taxa below $2 n=76$ and simple chromocenter type in those over $2 n=58$. Number and/or size of chromocenter may be at least partially related to nuclear DNA content. The duplication of genetic materials was pointed out to have played an important role in evolution (Ohno 1970), but it should be noticed that the reduction of DNA content took place in the course of speciation of some kinds of plant, for example, genera Lathyrus (Rees and Hazarika 1969), Vicia (Chooi 1971), Crepis (Jones and Brown 1976), Atriplex (Belford and Thompson 1981) and subtrib Microseridinae (Price and Bachmann 1975).

We thank Dr. Takuji Hoshino of Okayama University of Science for kind supply of all materials used in the present study. This study was partly supported by Grants-in-Aid from the Ministry of Education, Science and Culture, Japan (No. 244006 in 1979).

\section{REFERENCES}

Belford, H. S. and Thompson, W. F. (1981) Single copy DNA homologies in Atriplex. I. Cross reactivity estimates and the role of deletions in genome evolution. Heredity 46, 91-108.

Castro, D., Noronha-Wagner, M. and Camera, A. (1954) Two $X$-ray induced translocation in Luzula purpurea. Genetica Iberica 6, 3-18.

CHоOI, W. Y. (1971) Variation in nuclear DNA content in the genus Vicia. Genetics 68, 195-211.

Devies, E. W. (1956) Cytology, evolution and origin of the aneuploid series in the genus Carex. Hereditas 42, 349-365.

FAULKNER, J. S. (1972) Chromosome studies on Carex section Acutae in north-west Europe. Bot. J. Linn. Soc. 65, 271-301.

HALKKA, 0. (1964) A photometric study of the Luzula problem. Hereditas 52, 81-88.

Hoshino, T. (1980) Morphological and cytogenetical studies on the aneuploidy in Carex conica Boott. Bull. Hiruzen Research Inst. Okayama Univ. of Sci. 4-5, 33-41.

Hoshino, T. (1981a) Cytotypes of Carex oxyandra and their distribution in Japan. J. Jpn. Bot. $56,220-224$.

Hoshino, T. (1981b) Karyomorphological and cytogenetical studies on aneuploidy in Carex. $J$. Sci. Hiroshima Univ. Series B, Div. 2 (Botany) 17, 155-238.

JoNES, R. N. and Brown, L. M. (1976) Chromosome evolution and DNA variation in Crepis. Heredity 36, 91-104.

Koyama, T. (1957) Taxonomic study of Cyperaceae 7. The systematic position of Carex sect. Decorae with a taxonomic treatment of the Japanese species. Bot. Mog. Tokyo 70, 347-357. 
LA CouR, L. F. (1952) The Luzura system analyzed by $X$-ray. Heredity 6, 77-81.

Mello-Sampayo, T. (1961) Differential polyteny and karyotype evolution in Luzula, a critical interpretation of morphological and cytophotometric data. Genetica Iberica 13, 1-22.

OHno, S. (1970) Evolution by gene duplication. Springer-Verlag New York Inc.

Price, H. J. and BACHMANN, K. (1975) DNA content and evolution in the Microseridinae. Amer. J. Bot. 62, 262-267.

ReEs, H. and Hazarika, M. H. (1969) Chromosome evolution in Lathyrus. Chromosome Today 2, 158-165.

Smith, D. C. (1966) Development of the inflorescence in Carex. Annals of Botany 30, 475-486.

TANaKa, N. (1939) Chromosome studies in Cyperaceae, VII. Chromosome number and pollen development of Fimbristylis. Bot. Mag. Tokyo 53, 480-489.

Tanaka, N. (1940) Chromosome studies in Cyperaceae, VIII. Meiosis in diploid and tetraploid forms of Carex siderosticta Hance. Cytologia 11, 282-310.

TANAKA, N. (1948) The problems of aneuploidy. Hokuryukan, Tokyo

Tanaka, N. (1952) The problems of aneuploidy. Jpn. J. Genetics 27, 185-190. 